\title{
Body Thinking: From Chinese to Global
}

\author{
Kuang-Ming Wu \\ Philosophy Department, University of Denver, Colorado, USA \\ Email: Kmwu2002@yahoo.com

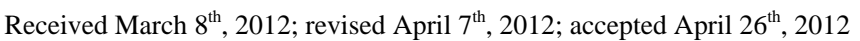

\begin{abstract}
This essay is devoted to calling global attention to body thinking neglected yet routinely practiced by us all, especially in China for millennia. This essay, one, responds to the feature, universality, of disembodied thinking, by paralleling it with Chinese body thinking, two, shows how basic body thinking is to disembodied thinking, and three, shows how body thinking in China elucidates bodily matters, time, contingency, and bodily death, what Western disembodied cannot handle.
\end{abstract}

Keywords: Body Thinking; Disembodied Thinking; Story-Thinking; Universality; Time; Contingency; Bodily Death

\section{Introduction}

1) This essay would have been an exercise in obvious futility, were it not for the mysterious fact today that thinking is usually taken as something bodiless. We had better, then, explain how obvious body thinking is. Obviously, no human being is without a body, a unique body per a unique person, every person thinks, and so no human thinking is not "body thinking" concrete and actual.

As human life is body living integral and holistic, so human thinking is body thinking, pure and spontaneous. Our body thinks as we eat and breathe. We breathe thinking in and out in mutual dialogues with things and matters, as well as among bodily persons, as we eat and drink not in reflex but humanly aware, as we think spontaneously.

By the same token, seen from thinking, thinking is not bodily thinking, as if thinking independently exists, and just happens to have bodily aspect. Actually, however, our human thinking is not at all appended with a haphazard body. Instead, thinking body-thinks. It is body itself that thinks; thinking is a feature of the body behaving-as-body. Thinking is our body thinking, actually, in shifting time and concrete places, and in our deep feelings quite intelligent. Examples from China the body-thinking culture help explain this natural fact.

Mencius of 2500 years ago passionately mentions our "heart" inherently sensitive “unbearable to people 不忍人之心," alarmed at a baby crawling into a well, and so much unbearably sensitive to an ox in mortal jitters, being dragged to sacrificial slaughter, as to release it. Five centuries later, Jesus was “ $\sigma \pi \lambda \alpha \gamma \chi \nu \imath \zeta o \mu \alpha$, in viscera-agony,” at seeing persons in pain. This word is used exclusively of Jesus and by Jesus in acts of mercy. ${ }^{1}$ Heartless cruelties directly incense us heartfelt, and we spontaneously wish to be the Good Samaritan helping those beaten half dead, in Buddha's "mahakaruna, great mercy."

Pain incites co-pain, co-pathos in com-passion. My son told me of being pricked himself as his baby was drawn blood for test, crying in pain. I was in tears hearing the story. Now, don't we see all such heartfelt co-pain-in China, in Buddha, in Jesus,

${ }^{1}$ Mencius 1A1, 2A6; “ $\sigma \pi \lambda \alpha \gamma \chi v 1 \zeta o \mu \alpha 1, ” \# 5072$ in The Greek-English Concordance to the New Testament, Grand Rapids, MI: Zondervan, 1997, p. 693 Buddha's "mahakaruna” is all over, in need of no citation. in my family_as body thinking com-passionately at work?

How could any one dare deny body thinking here total, reasonable, and life-moving? As we live to think, we constantly body think as we constantly breathe; we do not mind-think, not brain-think. Our whole body, our whole being, is directly involved in this body thinking as our body feels to live on. Our body lives feeling in body thinking. Body thinking is naturally heartfelt.

A reverse side of pain-co-pain complex in body thinking is imposing pain without co-pain. This pain-no-pain link shows our irrational passion, body un-thinking. Still, heartless cruelty incites our wholehearted indignation, and such incitement and indignation are body thinking at work. Our anger over Nero, Hitler, and Ch’in’s 秦 First Emperor produces floods of literature to wail out our human body thinking, tragically.

Unfortunately, we cannot prove that our tendency to violence is unreason. Reason cannot prove no-reason; reason cannot tell an absence of reason. We just see that violence is irrational impatience, but of course "seeing" is part of body thinking, and so in this direct seeing, perhaps body thinking "demonstrates-proves” the existence of violence as no-reason.

In the West, Arendt ${ }^{2}$ straightly considers violence in her turgid style, while China handles this strange unreason of ubiquitous violence by constantly describing it in history, in essays, and in fiction and dramas, but seldom thinks about violence as such. This situation is part of China completely dipping itself in history but never asking what history is. To think of it, though, doesn't violence so disastrous of China's Legalism and German Nazism stem from the preset regimen stoutly "disrobed" from people-actuality? With this notice, we leave this ugly theme of violence.

2) All such bodily situation heartfelt, thought-full, is so obvious so actual, as China honestly recognizes it to innocently and naturally practices body thinking for several millennia. The

\footnotetext{
${ }^{2}$ See Hannah Arendt, On Violence, NY: Harcourt, Brace and World, 1969 1970. In pp. 63-66, Arendt asserts that violence against injustice and hypocrisy is justified. I differ, taking violence to be an irrational ineffective affect, to be replaced with flexuous tactics of a tiger tamer, as Chang Tzu's Chapter 4 proposes. But developing this theme would take us too far afield from our context. Arendt is mentioned in Ted Honderich's wider Political Violence, Ithaca, NY: Cornell University Press, 1976.
} 
West cannot help but trying also to approach actuality. In the West, revolting, in the name of phenomenology, against Descartes' split of the mind-un-extended from body-extended, shows how the West has come of age in body thinking. ${ }^{3}$ But mysteriously the West still harbors love of Platonic impersonal analysis, trying to "see from nowhere" ( $\mathrm{Nagel}^{4}$ ), disembodied. Still, Western love of actuality is undeniable.

Perhaps natural actuality is intended in the following various schools of Western philosophy, theoretical cognitive exploration. We see approach to actuality in "common sense philosophy” of Reid and Moore, "naturalism” of George Santayana and Henry Nelson Wieman, and "existentialism” of Sartre insisting on existence before essence and of Merleau-Ponty seeing an intertwining of the flesh singing the world. ${ }^{5}$

Moreover, deconstructionism is out of fashion now but its general ethos lingers on. No philosopher today would carelessly tout naked logic; all thinkers are much "hushed" thanks to deconstructive revolution. Still, this ethos touches no "body thinking” explicitly, as it cannot help but handle bodily themes of insanity, power, etc. These are hopeful signs, but they are all still attached to "thinking" as widely logical-analytical, not thinking as one of our gutsy body thinking-behaviors alive.

In fact, whenever the West does notice body thinking, most thinkers rashly claim themselves all the way as being empiricists, naturalists, and even materialists, ever identifying "body alive" with mere physiological functions. Thinkers such as Nietzsche, d'Holbach, Schopenhauer, Hobbes, Santayana, Sartre, and so on, come to mind. Taking body alive and whole as "mere physiological functions" shows their deeply embedded mode of disembodied thinking disrobing body alive into a mechanical object to handle.

3) Time is overdue for the world, China and the West in it, to squarely face up to this basic, obvious, and essential life-activeity of body thinking, and we will all then have life-revolution in actualizing our thinking. Since China has been doing body thinking for millennia, it is natural that the West should pay attention to it with critical scrutiny.

\footnotetext{
${ }^{3}$ See, e.g., a convenient anthology, Stuart F. Spicker, ed., The Philosophy of the Body: Rejections of Cartesian Dualism, Chicago: Quadrangle Books, 1970.

${ }^{4}$ Thomas Nagel, The View from Nowhere (Oxford University Press, 1989). We will soon return to him.

${ }^{5}$ See a convenient anthology, Thomas Reid's Inquiry and Essays, eds. Keith Lehrer and Ronald E. Beanblossom, Indianapolis: Bobbs-Merrill, 1975, "G. E., Moore" in The Concise Encyclopedia of Western Philosophy (1960), Eds., Jonathan Rée and J. O. Urmson, London: Routledge, 2005, pp. 259-261, and William L. Reese, Dictionary of Philosophy and Religion, Amherst, NY: Prometheus, 1999, pp. 495-496. George Santayana, Scepticism and Animal Faith (1923), NY: Dover, 1955, and Dialogues in Limbo (1926), NY: Charles Scribner's (1948), where we even smell philosophy to discover it. A convenient reference can be found in The Empirical Theology of Henry Nelson Wieman, Ed., Robert W. Bretall, Carbondale: Southern Illinois University Press, 1963; it has his bibliography till 1962. See a convenient anthology with useful bibliography, Jean-Paul Sartre: Essays in Existentialism (1965), Ed., Wade Baskin, Secaucus, NJ: Citadel Press, 1974. See Maurice Merleau-Ponty, Phenomenology of Perception (London: Routledge \& Kegan Paul, 1962), The Primacy of Perception (1964), The Visible and the Invisible (1968), and The Prose of the World (1973), among others. The last three volumes are from Evanston, IL: Northwestern University Press. Emotivism of David Hume, Charles Stevenson, and Paul Edwards is omitted; see its dreary criticism in J. O. Urmson, The Emotive Theory of Ethics, Oxford University Press, 1968. An obvious example of Marcel, my idol, is omitted as well. He would be the closest thinker in the West to body thinking, perhaps the only "oddball" to my general description of the West here. See a convenient The Philosophy of Gabriel Marcel, Eds., Paul Arthur Schilpp and Lewis Edwin Hahn, La Salle, IL: Open Court, 1984, with useful bibliography.
}

China's innocent body thinking will then be carved and shaped out saliently by responding to the West's queries. Thus, critical dialogue enlivens body thinking; in fact, dialogue is possible only among full-bodied thinkers. Strangely, however, Plato's Dialogues soar up to disembodied Forms while the dialogue partners are all bodily persons, not fairies of pure ideas.

4) Professor Zhang Zailin has solidly pioneered body thinking as essential in China, as I pioneered it in Taiwan by publishing it in the Netherlands. Mine was criticized as lacking in Chinese citations, and Professor Zhang's volume came along to respond to it for me. ${ }^{6}$ Zhang's book, Traditional Chinese Philosophy as the Philosophy of the Body, is systematically arranged to elucidate body thinking in China.

In the introduction-modestly called "preface"-Professor Zhang issues a clarion call. Body thinking has been the backbone of traditional Chinese philosophy yet, strangely, it has not been noticed so far anywhere, and so noticing it amounts to a revolution in our purview and understanding of China. Zhang's book then opens out into two divisions and two appendixes.

Division One elucidates in four chapters the bodily feature in China's cosmology, ethics, religiosity, and history. Division Two details these themes in Chapters 5 through 11, meticulously depicting "family", "Change Classic", "body politic", "body knowledge”, "body-philosopher Wang Fuzhi”, "novel, Dreams of the Red Chamber", and "the necessity of exploring body thinking in China". Appendix One reports on three directions of exploration into body thinking in China. Appendix Two details the budding "New Feminine" in China today.

Now, it is obvious that Chinese culture is composed of its distinctive cosmology, socio-ethics, and religious reverence, all of which begin at family to expand to the classical poetry of cosmic change, both of which are based on body knowledge. Zhang sensitively demonstrates all this in body-philosopher Wang Fuzhi's thinking and the well-known fiction of Dreams of Red Chamber, to conclude with reports on the necessity of body thinking, three directions in its exploration, and the budding ethos of "new feminism" out of body thinking.

Thus, differing from the usual analyses of small topics and details so common throughout academia, Professor Zhang's volume is the first ever comprehensive bird's eye view, anywhere in the world, of the entire Chinese culture and philosophy as body thinking, from bodily bisexuality of the cosmos to its historical process ongoing.

This book of Zhang's clearly announces to the whole world the essential significance of body thinking, not in vague generality but from the concrete perspective of Chinese thinking as a whole. It is a pivotal trailblazer. This volume has abundant materials in China, in ancient bodily ethos pervading today, on body thinking in China. Its coverage is so careful and comprehensive that nothing is left to be desired.

Of course, we could quibble about the book on its lack of distinction between sex and gender together with the lack of their involved relations, as Merleau-Ponty also failed to do, and a lack of overall coherence, but Professor Zhang can easily respond that his book essentially blazes the trail of body thinking by elucidating it in terms of China.

\footnotetext{
${ }^{6}$ Zhang Zailin, Traditional Chinese Philosophy as the Philosophy of the Body, Beijing: Chinese Social Sciences Publishers, 2008. Kuang-ming Wu, On Chinese Body Thinking: A Cultural Hermeneutic, Leiden, the Netherlands: E. J. Brill, 1997.

"The Body in Its Sexual Being" should have been "in gender being" in Maurice Merleau-Ponty, Phenomenology of Perception, London: Routledge \& Kegan Paul, 1962, pp. 154-173.
} 
And so, such niceties demanded by critics can easily be preened by and by, by the critics themselves, in the major body-historical direction set by his book that portrays body thinking alive, quite impossible to sum up in a set neat formula, as any child jumping alive so protean, daily growing, can never be capsuled in a preset pattern.

In contrast to Zhang's conscientious probing of Chinese body thinking, my approach in the book, Chinese Body Thinking, is to critically dialogue on body thinking with an explicit exponent in the West of body thinking (though he did not use this phrase), Maurice Merleau-Ponty. I tackle him round and round, to go from China to him, and then go from him to China, both routes in critical dialogues. I did Chinese body thinking interculturally, while Professor Zhang dug deep into China as such.

We form a good complementary team. Kant in his disembodied analyticity was still conscientiously observant enough to notice our pair of hands to be asymmetrical counterparts that compose our body to orient us in the world. ${ }^{8}$ Professor Zhang and I form such fitting counterparts asymmetrical in body thinking.

5) I now continue my approach of critical dialogue on body thinking with the West, by facing up to the Western challenges to body thinking practiced in China, in pages that follow. Of course in the dialogue between equal partners, China and the West, the enormity of Western contributions cannot be neglected. Thanks to the exactitude and accuracy of its disembodied thinking, we all now enjoy various harvests of engineering, heavy metal routinely air-flying and ocean-floating, medical advances to advance longevity, nuclear power conveniences, and even outer space explorations.

Still, since resounding kudos on disembodied thinking in the West has been sung so loud for too long, it is time to balance, however belatedly, our logical attention and stress the indispensability of body thinking no less crucial and, in fact, basic to disembodied thinking and to human living.

This essay is thus devoted to calling our global attention to body thinking that has been completely neglected yet routinely practiced by us all, and especially in China for millennia. Now, one must shout to call attention to body thinking, and shouting for it can sound unfair to disembodied thinking. For this essay's partiality to body thinking, and over-emphasis on it, we plead understanding forgiveness.

This essay shall, one, respond to the standard feature, universality in space and time, of disembodied thinking, by paralleling it with Chinese body thinking, to demonstrate how body thinking does have such feature of disembodied thinking. And then, two, this essay shall show how indispensably basic body thinking is to disembodied thinking that is in fact a part of body thinking,

Finally, three, this essay shall show how body thinking in China elucidates matters in bodily life, such as time, contingency, and bodily death, that Western disembodied thinking lacks and so cannot handle, for such thinking has none of them, and cannot think clearly-coherently about such important mat-

\footnotetext{
${ }^{8}$ Immanuel Kant, Kant's Inaugural Dissertation and Early Writings on Space tr. John Handyside, Chicago: Open Court, 1929, and the Critique of Practical Reason and Other Writings in Moral Philosophy, tr. Lewis W. Beck, University of Chicago Press, 1949. They are conveniently but insufficiently collected in The Philosophy of the Body, ed. Stuart E. Spicker. Chicago: Quadrangle Books, 1970, pp. 90-97. We will return to Kant in our later section on body thinking as basis to disembodied thinking.
}

ters in embodied living. ${ }^{9}$ To repeat this important point, being not embodied-actual, disembodied thinking has no motion in thinking, no actual contingency, no bodily death, and so of course it cannot handle them. Now, we go into these three sections one by one.

\section{Body Thinking Paralleling Disembodied Thinking}

Disembodied thinking would condescendingly say, "Our lived body is so fragile, how could our body think? Body thinking cannot be, unless it thinks of 'universality' in space and in time, and fragile body is only for a while, and no more, right?” All right, to simplify, let us agree that thinking consists in thinking "universally"10; let us consider how bodily ubiquity parallels disembodied universality, space-wise and time-wise.

We must note here that disembodied thinking has no universality in space or in time, for disembodied universality is gained by leaving actual space and concrete time, and so its universality is out of space and time, anywhere any time without touching time or space at all. In contrast, bodied ubiquity goes through actual space, at home in time. With this understanding, let us see body ubiquity in space, then in time.

1) Disembodied thinking "spreads" in space by space-less universality, and so such thinking does not literally spread but just stays indifferently as it is, anywhere, nowhere. In contrast, body thinking actually spreads all over by naming things. Chinese etymology of “name 名” says that ${ }^{11}$ naming is a bodily act. In the dark of the vague dusk (夕), the mouth (口) calls out a name (名), thereby the "horse" stands out (立). And the "horse 馬” in China serves as a common cipher (碼) to stand for things.

Things come into being to our notice by our naming them. No naming, no thing. Naming stands "things." Now, naming is our body perceiving. As Berkeley famously said, "To be is to be perceived,"12 so China's body thinking in Hsün Tzu (Chapter 22, 正名篇) would say, “To be is to be perceived and named." A white horse comes to be "white horse" only by being so seen-named, as any horse would be so named to be "horse," says Name Scholar 名家. Naming is body thinking at work, ontologically.

Naming is also body thinking cosmological. Naming goes

${ }^{9}$ For example, Martin Heidegger would say, "facticities” of "contingency" and "physical death" are where thinking must stop. However much natural science tries, there remain stubborn contingent exceptions. Søren Kierkegaard's The Sickness unto Death (its first translation appeared in 1941, Princeton University Press) is closest to thinking about death in the West, but it is on death-agony in life, despair, not on bodily death. Perhaps Kierkegaard's thinking was closest to body thinking, and so he thought about thinking of death, though in the realm of life. No jesting in thinking, essential in time, exists in Western philosophy. We will detail on time and its attendant play in irony, contingency, and bodily death, to conclude our essay.

${ }^{10}$ Let us set aside the thought of "instant thought"; going into the theme will take us far afield, though we must warn disembodied thinking that thinking always happens in an instant-thinking is a unity of "always" and "instant," for "always" is nowhere without "instant"-and disembodied thinking has no instant. Does it mean disembodied thinking does no thinking?

${ }^{11}$ See 說文解字詁林, 臺北市鼎文書局, 1983, 2: pp. 1154-1157. In contrast, English "name” has no etymology behind its surface meaning. See Oxford English Dictionary, Second Edition, 2001, X: 201, and The Oxford Companion to the English Language, Ed., Tom McArthur, 1992, p. 678.

${ }^{12}$ Sadly, Berkeley said so not to dwell in bodily perceiving but to hook the saying on to the eternal God who perceives always to keep things existing. This is his "proof" of God's eternal existence timeless and space-less. He is in the realm of disembodied thinking. 
from a specific "white horse" to many horses-in-general. This generalization process goes on because "name" is not owned privately but shared-agreed among the social public, and yet the public-in-general does not name but it is "I" an individual who names, as Name Scholar cautions that (specific) white horses are not (general) horse. So, my mere act of "naming things" tells of I-things ubiquity in I-society spread. Naming shows how I was born in my family to spread to society, which in turn expands throughout the cosmos as a big family.

2) Similarly, disembodied thinking "lasts" timeless, staying indifferently outside time. In contrast, body thinking actually lasts in time, through history-transmission by storytelling-in books, in education - from one generation to another. Of course, our human body lasts only for a century or less. And yet, this fragile body's saying so lasts and lasts in time. "People born between heaven and earth are as white colt passing door-crack, only so sudden”, said Chuang Tzu (22/39), and this saying has lasted for 2500 years, to last into the future unlimited. Words so ephemeral are amazingly incorruptible.

By the same token, personal integrities (virtues) and private achievements (merits) are transmitted, by the most fragile words yet incorruptible, into their incorruptibility of respective sorts. In fact, this very saying about Three Incorruptibles 三不 朽 was casually made (in 左傳, 襄公二十四年) when Confucius was only a child of three, and this saying has been lasting till today and will last into the future far beyond today.

3) We note that it requires human body to say and hear sayings. All this composes not indifferent eternity but actual incorruptibility of body thinking. We call it "history", as China is the culture of storied-history 文史 in body thinking. It is body thinking that produces history story-told. Thus concrete spatiotemporal ubiquity in body thinking parallels abstract universality, timeless, space-less, of disembodied thinking.

Now, this body-approach to thinking bypasses to dissolve a conundrum eked out by separatism of disembodied thinking. Descartes says the mind alive is not the body extended. Marcel says I have no body, for I am my body. There would be no such problem of dichotomy possible-body separate from mind vs. "I am my body"-if my body itself thinks, if my spirit is the animated élan of my body alive. Besides, my body is body socio-politic, homo-cosmic, and so I am macrocosm writ small as the cosmos is my body writ large. Unity in diversity of myriad things exists in Heaven and Earth.

4) Someone careful may say, "All this ubiquitous incorruptibility works when the body is taken collectively. What about the body of an individual person, though? When an individual body is gone, it is gone, and no more universality is left, right?” To this demur, two responses must be respectfully made.

One, the above description does not take body collectively, for "collective body" does not exist. Body is always an individual person; the above description takes human body individually as my body, as your body. This body-act—via my individual naming that is socially charged-spreads through family to my community, to make a big cosmic family of all myriad things through time, as naming lasts long, as horse is "horse" to me as it is to my parents and to my grandparents as it is to my children and my grandchildren.

Two, of course each individual body soon dies away. Still, sober disembodied thinking will then be surprised to find body thinking celebrating the joy of bodily death that goes on alive incorruptible, and the joy is both individual and cosmic. We will describe this incredible joy in the concluding part of the present essay. Excitement is still ahead of us, my friend. Just you read on.

\section{Body Thinking as Basic to Disembodied Thinking}

"If those two thinking modes-disembodied and bodyparallel, then we can do either disembodied thinking or body thinking, right?" To correct this natural reaction to the above description, we must realize that body thinking is at the base supporting disembodied thinking, which would be toppled down baseless if we do not attend to body thinking. To show that the base of disembodied thinking is body thinking, we will show how disembodying assumes being embodied, how "seeing” as theorizing stops without our body seeing, and how all key operations of disembodied thinking vanish without body thinking.

1) To begin with, disrobing cannot happen without having robes before taking them off. Disembodied thinking cannot take place without having body thinking in the first place, and it takes labor to take off body thinking. This is naturally shown in the laborious dialogues displayed by Plato to step by step take off body thinking.

The Allegory of the Cave in the Republic (vii. 514a-521b) is a graphic summary of such disembodying process attended with ultimate violence, murder of the pioneer of disembodied thinking. This is because body thinking is seen in a violent way, to wit, body is our chain of illusion, inborn and firm, from which we must be unchained, violently if need be.

This thought originates in turn in an illusion that body thinking cannot attain the necessary universality that disembodied thinking supposedly attains. That this assumption is itself an illusion is exposed by the paralleling of body thinking with disembodied thinking in our previous section. Now that their parallelism is shown, we need not disrobe our body, need we?

2) Moreover, the situation is in fact worse than described above. The eternal ideas envisioned by disembodied thinking cannot happen without "ideas" and "vision”. Ideas-from idein, see-are seen, and seeing cannot happen without the body seeing. In fact, "theorization"-from thea, act of seeing ${ }^{13}$ — so proudly touted by disembodied thinking, is just seeing, nothing else. "Seeing from nowhere” as prominently advertised by disembodied thinker, Thomas Nagel, ${ }^{14}$ cannot happen, for seeing always sees something there by a bodily seer here. Seeing is concretely spaced, and concrete spaces are inherently body-charged.

"Seeing from nowhere" thus destroys the very seeing itself that is made possible only by the body seeing. "Disembodies thinking” makes theorization impossible. Therefore, theorization ceases, thinking stops, when thinking disembodies itself. Surprising as this conclusion may seem, it is an inevitable result of disembodying. All this amounts to saying that disembodied thinking is based on body thinking. Now, let us detail this general description by looking into concrete operations of disembodies thinking, one by one.

3) Thinking, bodied or disembodied, begins when I see what you mean, and then we argue about the point proposed; to mean is to mention what you have-in-mind, and to argue is to plead and to respond, and we need a body to propose. ${ }^{15}$ To see, to

\footnotetext{
${ }^{13}$ See Merriam-Webster's Collegiate Dictionary, 2008.
${ }^{14}$ Thomas Nagel, The View from Nowhere (Oxford University Press, 1989.

${ }^{15}$ What to see, to mean, and to argue mean are taken from Merriam-Webster’s Collegiate Dictionary, 2008.
} 
mean, to argue, and to propose are all body-acts. Again, thinking, bodied or disembodied, logicizes and understands; to logicize is to bundle, ${ }^{16}$ and to understand is to stand under to undergo an idea. To logicize and to understand are both body-acts.

Mathematics is the home and the bone of disembodied thinking arguing. Kant observes that " $7+5=12$ " is a priori rational but must rely on extra-analytical synthesis of 7 with 5 to conclude 12 , for 12 is not analytically contained in 7 or 5 as "unmarried" is contained in "bachelor," so he calls mathematiccal operation synthetic a priori. The a priori arithmetic acts body-synthesis. Merleau-Ponty then observed that geometry proceeds by body moving from one spot to next. Arithmetic and geometry are body-acts. Kant says, our body-awareness of right-left, front-back orients us to cosmology. ${ }^{17}$

All these bodily operations are pivotal in disembodied thinking, and so disembodied thinking is based on body thinking. In short, no body, no disembodying, and disembodied thinking continues to do body-operations as its pivotal essential argumentation. Disembodied thinking vanishes when body thinking leaves, as surely as "seeing from nowhere" ceases seeing.

Put it another way, we can simply say this. Words of mouth and acts of hands in body thinking produce storytelling, which includes poetry, fiction, history, to inquire into matters to gain knowledge and report its stories in history, ${ }^{18}$ fiction, poetry, mathematics, and arguments. For reasons of "precision, exactitude, and clarity", disembodied thinking engages mathematics and arguments alone, as if history and other genres of storytelling are not exact, precise, and clear enough.

China shows how mathematics is also part of body thinking, but in an unexpected way of clothing math in self-cultivation in the homo-cosmic universe. The Confucians would study and time and again practice it, to geometrically shape the self, to daily self-invigilate three times to arithmetically add self-stature, to adjust the family and pacify the world. The Taoists would learn to add daily to lose in cosmic Tao daily, all synthetic a priori operations.

Then the Taoists would smile and sigh, "I used to pity people self-losing, then pity those who pity them, then pity those who pity those who pity them, but such days are far gone now”. All this is to self-grow in time-geometry synthetic a priori. China has mathematics as time-poetry in Change Classic, dragon-soar some time, snake-slither some other time, always timely measured, intimately harmonious, "thinging things". ${ }^{19}$

4) A further piece of evidence can be adduced for this claim of body thinking as the basis of disembodied thinking. Thinking operates by concrete notions and abstract concepts. Notions are noted within actual situation; concepts are abstracted from actual matters. Noting and abstracting are impossible without the body acting as thinking.

Thus disembodied thinking operating in notions and concepts would have been impossible without body thinking. It is what we meant when we said, to repeat, disembodied thinking is

\footnotetext{
$\overline{{ }^{16} \text { On "logic” as "bundle”, see my On Metaphoring: A Cultural Hermeneutic, }}$ Leiden: Brill, 2001.

${ }^{17}$ On “7 $+5=12$ " as synthetic a priori, see Immanuel Kant's Critique of Pure Reason, B15-17. On geometry as hand-operated, see Maurice MerleauPonty, Phenomenology of Perception, London: Routledge \& Kegan Paul, 1962, pp. 384-386. On Kant's insistence that our body orientations originate our cosmological knowledge, see his Critique of Practical Reason, University of Chicago Press, 1949, pp. 294-295.

${ }^{18}$ History is linked etymologically to story that means to inquire to gain knowledge.

${ }^{19}$ Analects 1/1, 1/4, Tao Te Ching 48, Chuang Tzu 24/64-65, 20/67.
}

dis-bodied from body thinking as disrobing is done by taking off the robe-covering, and now we can add, disrobed disembodied, the body vanishes with thinking itself.

Actually, it is incredibly difficult to take off our body we are born with. It laboriously took Plato so many Dialogues to "disrobe” body thinking into disembodied thinking, as dramatically described-crystallized in myths and the Allegory of the Cave. After all, thinking is done alive, and every human being here now thinking is body-alive.

And so all thinking is body thinking, together with its selfimposed derivative, disembodied thinking. Unfortunately, simply due to its restriction, disembodied thinking ends up cutting off many topics of body-living handled routinely by body thinking. To this final clinching theme we now turn.

\section{Life Outside Disembodied Thinking: Time, Contingency, Bodily Death}

Not only does body thinking parallel disembodied thinking; not only does body thinking support disembodied thinking at its base. Body thinking in addition can routinely do things that disembodied thinking cannot, simply because time is an ingredient of body thinking but is out of bound of disembodied thinking. This simple feature, disembodied thinking as having only timeless space, ${ }^{20}$ results in its three consequences quite serious, to wit, lack of time, lack of contingency, and lack of bodily death, as compared with body thinking.

Consequence One: Time

1) First, in disembodied thinking, time is a mere "shadow of eternity" entirely timeless. Shadow is unreal; what is real is eternal, not time that moves. Aristotle's thinking thinks thinking; it is the "unmoved mover" itself not moving, to move others that are only shadows. So, Aristotle is just cheating himself fooling around with the phrase, "unmoved mover".

In other words, disembodied thinking has no time, and so such thinking has no motion, as Zeno correctly intuited. The problem here is, though, Zeno could not have proved his thesis, for proving, arguing, takes time to move from premises to conclusion. So, proving no-motion is to move to deny moving. It is entirely impossible.

Disembodied thinking has no time, only space universal eternal, so it has no motion, and so it cannot even think. Thinking and arguing moves, and is itself impossible in disembodied thinking. Time implicates change, 1) change in space, locomotion; 2) change of direction back and forth in time, in implication; 3) change of self, metamorphosis, e.g., growth, changing mind in gestalt, in assumption, in inter-living. All such motions and changes are entirely impossible in disembodied thinking immobile. Simple locomotion alone is a contradiction, as here and not-here.

2) But time-sired motions are what life-actuality is, as shown in the six features below, which are completely outside disembodied thinking. As a result, disembodied thinking incurs six impossibilities, future-hope-plan, past-history-as-present, playirony, self-examination, impact-imagination, and alive-changing.

First, thinking not just of things but as the very change of its mode and its direction belongs to hope and plan for the future. Future-thinking is possible only in body thinking growing un-

\footnotetext{
${ }^{20}$ Actually, space can only be here and there and everywhere, and they are bodily concrete, and so bodiless thinking would not even have space. But we would let go of this point to simplify the matter.
} 
ceasingly. In the unchanging eternity of set disembodied thinking, such future-thinking is unthinkable.

Secondly, time-thinking involves prospective retrospection in prospective history, the lively past created only by bodily us at present to point us forward. This is storytelling forever novel, yet stories can be told only of what has happened, even in imagination of our future. Science fiction takes off from what we already know, and "already" is the past. Such dynamics of time-flow to and fro is impossible in static disembodied thinking.

Thirdly, even mild metaphor that tells of this to point to that is despised by disembodied thinking as a frivolous dispensable decoration. Body thinking not only thrives in metaphor; it even revels in irony, telling this to deny this or deny that, and winks at the listener. Lin Yutang said, Chuang Tzu is frivolous when profound, and profound when frivolous. ${ }^{21}$ Chuang Tzu does so by playing even with argument ${ }^{22}$-bits and story-bits. Such a play-stunt can never be pulled off by no-mouthed disembodied thinking timeless.

Fourth, time-thinking in body thinking is self-reflexive, and so self-examination to self-adjust and change, urged by Confucius and Socrates, can happen only in body thinking. Disembodied thinking cannot look back; it only looks in one direction to eternal Forms of ideals unchanging. In fact, even "looking" without eyes is impossible in disembodied thinking. Forms are just there, stark and logical.

Fifth, thinking makes impacts on life only by body thinking. Impacts can be made even by imagination that fictively projects actuality beyond actuality, and making real impacts makes imagination real. Fictions are more real than mundane reality. Impact is made on concrete bodily living, and so all this is unthinkable in disembodied thinking. Sixth, in short, body thinking is alive natural. No disembodied thinking anti-natural can be alive at all.

3) Moreover, the third and final consequence of disembodied thinking must be added to this list quite serious. Body thinking naturally elucidates two tough matters in life-actuality that disembodied thinking is unable to handle, i.e., actual contingency and bodily death, simply because disembodied thinking is disrobed from body-actuality. Let us consider first "contingency", then "bodily death", and see how naturally and beautifully body thinking handles each of them.

Consequence Two: Contingency

1) Contingency has long been a chronic headache to disembodied thinking that tries vainly to tame it with statistics. Its statistics so incredibly complex tells not how complex actuality is but how inept disembodied thinking is, how incapable it is of handling our daily straightforward contingency in actuality.

Contingent particulars always "leak through" the general average concocted by disembodied thinking; they always come in as stubborn "exceptions" to the neat "natural laws" painstakingly devised by disembodied thinking out of controlled experiments. To say that natural science-our knowledge of nature-is ever in progress is a euphemism for its constant errors, exception-riddled.

2) But in fact contingency is just actuality alive natural as our body is natural alive; this "as" rhymes contingency with body

\footnotetext{
${ }^{21}$ Lin Yutang, The Wisdom of China and India, NY: Random House, 1942, p. 627.

${ }^{22}$ My meditation on "playing with arguments" is done by watching Chuang Tzu. See Kuang-ming Wu, On the "Logic" of Togetherness: A Cultural Hermeneutic, Leiden, the Netherlands: Brill, 1998, pp. 150-293.
}

thinking that actually thrives there. Body thinking never "tames" or "controls" contingency. Instead, body thinking naturally tells stories of its mathematical poetry whose bodily participants we are, as Change Classic the I Ching 易經 adumbrates, intimates.

China calls such rhyming intimacy "history" that continually weaves out the continuous network natural alive into crisscrossing literary stories, wen 文; China is cultured with storied history 文史, in Yin and Yang internecine inter-nascent among the cosmic Five Agents 五行, as woe and weal inter-lean-on to inter-lurk-under (Lao Tzu, 58).

We live on the edge of contingency as our home. Our situation is told in a Huai Nan Tzu's story of Uncle Fort at the city-limit of expectation, forever expecting the unexpected, ever asking, "How could this woe not do weal?" and then "How could this weal not do woe?" In this way, we are ever experienced and body-prepared, serving ourselves as weathered weatherman and bodyguard of safari walkabout, living on in contingent ongoing. We follow along body-actual, riding on waves of winds, to turn into birds, "storm petrels," soaring in the uncertain air, vast and sky high.

Body thinking in such story-way adapts - come what mayto adapt whatever comes to feed life, growing and blossoming as flowers out of mud, not muddied. We are Chuang Tzu's (17/81-84) slow turtle that must drag its tail in the wet mud to thrive, not to be cleaned up and shuffled up embalmed in the dry abstract Platonic Altar so neat, glorious, and dead.

Ugly muddy events are now beautifully told as history alive, unending, by the grand historians of all ages. Contingency is humus to story-thinking in body thinking; body thinking is at home in none other than messy contingency itself. All this body-story-thinking is actuality-thinking in history-thinking, lustily intoning our Yin-Yang living natural alive.

3) Let us put the whole matter of contingency another way. In the West, proving validity against falsehood is indispensable, for disembodied thinking leaves actuality as it tries to apply itself to actuality. The gap made by leaving away and coming back thus must be crossed, and the crossing often goes amiss. Therefore, proving and checking on validity is required in all operations of disembodied thinking, yet verification requires getting out of disembodied thinking to be done by disembodied thinking. Such a self-defeating operation keeps disembodied thinking busy for ever, in vain.

In fact, this self-defeating disembodied thinking more than "labors in vain"; it harvests disaster. Disembodied thinking sires perfectionism pining after whatever pies in the sky ever separate from the bodily present, to result in mistreating our own body, such as eating disorders in overeating or hatred of eating, and compulsive over-exercises, to ruin our body-self. Disembodied thinking ruins the body to ruin body thinking, to ruin disembodied thinking in return. The cure is, of course, body thinking. It goes this way.

In contrast to disembodied tragedy, as body never lies (for I am what I am), my body thinks in and with things (as body is one thing among things), and things do not lie (for things are as they are), and so body thinking is naturally true to things and true to our body. Checking is out of the question here, for the body is ever at home in what it is, in no need of pining after pies in the sky.

Unfortunately, our body gets sick once in a while, and then it is overrun by things coming and by body self-twisted. And so, “correcting names 正名” in “self-reflective examination 自省” 
is required to adjust body thinking back to itself among actual things. I ad-just what I mean (names I profess) back to my body-actuality, by self-examining how twisted my self-image is.

In doing all this self-reflective activity, we must remember that name-correction and self-reflection are themselves body thinking at work not-lying to itself and to things. Now, where is the need to independently verify and prove validity? Isn't body thinking the cure of disembodied thinking and its disaster?

In sum, we see how the whole world keeps changing. Myriad things keep coming to keep body thinking alive; body thinking is as alive as things are. Countless things are alive, i.e., contingent, ever changing without prior notice; the situation is quite a headache to disembodied thinking set in prior rules set by disembodied thinking itself, while body thinking alive flexes with things contingent, thriving in contingency as its home.

Consequence Three: Bodily Death

1) Now, the ultimate limit of life-contingency is its cessation, bodily death. Completely out of bound of disembodied thinking, it is here in bodily death that body thinking is at its beautiful best at handling it in story-thinking. Stories must be told by words of mouth. No wonder, Western disembodied thinking lacks story-thinking. Let us take five stories, all proposed with an impish wink by an ancient friend of ours, 2500 years young; he is that unconquerable Chuang Tzu story-frolicking even in bodily death.

Disembodied thinking has separated itself from the body, so it has no bodily death and cannot handle it. In contrast, bodily death is an intimate integral aspect of body thinking. It thinks on-not of-bodily death to show how body thinking goes beyond Western materialism, how body thinking reveals "actual eternity in time and space," and how bodily death is even excitingly natural alive, quite cosmic.

Thus body thinking opens up a novel horizon no Western disembodied thinking would ever envision at all. Only body thinking can pull off such stunt, unheard of in disembodied thinking. Significantly, body thinking opens out this novel milieu via storytelling embodied concrete, as a matter of fact description, thoroughly historical beyond factual history.

2) Let me repeat. Death is at the rock-bottom limit of life natural alive. Incredibly, here are five stories on death in an ascending order of joy. They are bequeathed by Chuang Tzu of ancient China, who is jumping alive today among us. His five vibrant stories are here, singing at his wife's death, dreaming to be a butterfly, Lady Beautiful happily kidnapped, some bosom friends in joy seeing off their dearest friend on death-journey, and the absolutely ineffable joy of a dry skull casually doing vast season-rounds.

These five stories of Chuang Tzu's are playful stations in our changes by death. Or rather, they are ebullient stages of our changes into natural death alive. The farther we go into death, the happier we turn, until we ourselves become Joy Ultimate with Heaven and Earth, natural alive, precisely at the rock-bottom miseries of life-now-dead.

We will now go into these delightful death-stories, one at a time, all incredibly natural, all alive-in death. These deathstories so natural require no transcendent divine to crank out joy in death. These stories are all told by Chuang Tzu alive today, precisely in death, after these 25 centuries.

Death-Story One, Chuang Tzu Singing on His Wife's Death (18/15-19):

Chuang Tzu's wife died. Hui Tzu went for condolence, and found him squatting drumming a bowl, singing. Hui Tzu said, "With her you lived, raised kids, grew old; at her death no weeping is already enough. You even squat and sing, isn't it too much?” Chuang Tzu said, "Not so. At her death, was I alone in no deep feeling? Reflecting on the beginning, as I calmed down, I saw that originally there was no birth, no body-form, not even breath.

And then, in jumbling I-know-not-what, change came to have breath, and birth brought body, which now changed again into death-all this change changes with the four seasons turning. She now sleeps in a vast room, while if I were to wail after her, isn't it not-aware of destiny? So I stop." ${ }^{23}$ Now, can any cutting edge science today go beyond this description? All that our sciences do is to say such and such a change is what just happens, what sciences call "contingency"; such is a "jumbling I-know-not-what,” isn't it?

The poignant point expressed in this incredible story is deeper, more concrete, and more colorful, natural, and actual, than the long-faced Stoic ataraxia, apathy, in the teeth of death, for Chuang Tzu sings drumming on an upturned empty bowl. No Buddhist would have feelingly done so. What moving chanting, what meditative wailing that sings itself out, into soft sensitive kindness to his dearest wife, now at rest in the restive nature-process, as nature-inevitable as autumn turning into silent snow of winter!

Could Chuang Tzu have gently told Rabbi Kushner, who lost his dearest son so young, that his cherished treasure had previously come as spring blossomed flower of youth, and then now has silently dissipated into the Process of winter snow no less alive, and so it is best not to disturb his son's ongoing peace of sleep?

Doesn't such kind calm sensitivity go in fact farther to soothe the living and the dead than a Buddhist austere emptying of life-transmigration? Doesn't this sensitive insight go far beyond chilly physics and physiological sciences today? No wonder, the story is already at the height of a death-insight that amazes Waley. ${ }^{24}$

Death-Story Two, Dreaming to Be a Butterfly (2/94-96):

However scientifically enlightened, seeing death as a dispersing of the autumn leaves into winter snow is a view from a usual living. Matters may possibly be quite different, seen from the point of view of death. This exciting possibility, no less natural alive, is pointed to in the story of Chuang Tzu dreaming to be butterfly and awakening from it into deep puzzlement. It goes as follows.

"Last night, Chou (my name) dreamed as butterfly. Flitting and fluttering, I was butterfly, freely going as intended, not knowing Chou. Suddenly I awoke. And then, so thoroughly it was Chou. Now I do not get it: is it I knowing Chou to have dreamed to be butterfly? Is it the butterfly knowing it now dreaming to be Chou? Chou and butterfly then must have distinction. This it is that is called things changing.,"25

1) Now, "butterfly" is the world-ubiquitous wonder-name of something alive and natural, flitting to and fro between death

\footnotetext{
${ }^{23}$ This is my translation, the original abridged yet kept to its original vigor.

${ }^{24}$ Arthur Waley, Three Ways of Thought in Ancient China (1939), CA: Stanford University Press, 1982, p. 6, cf. 30-32. Harold S. Kushner's When Bad Things Happen to Good People, NY: Schocken Books, 1981, is a Judaic view so brave, so desperate, and so popular.

${ }^{25}$ Again, this is my translation of the vigorous poetic original, in as literal an expression as possible without falling into unintelligibility. See my The Butterfly as Companion, Albany: State University of New York Press, 1990, p. 493 (index on "butterfly").
} 
and life. It flutters between dreaming and awakening, each with its own criteria of what is real and what is not, to interchange to inter-change. "Distinct" and "things changing" are two phenomena daily common, ubiquitous, and quite crucial among matters there are, in death and in life.

For example, I am not at all a baby, as the baby is not me. Only thus distinct can I hug the baby, and we both giggle for sheer joy of living together. We then change into each other so much so that I do not know if the baby is hugging me or I am hugging the baby. The baby thus parents the parents, and we both grow into the future. ${ }^{26}$ All this is an everyday happening. Chuang Tzu's genius lies in radicalizing this life-precious fact into dreaming and awakening to connote life and death.

Am I, a man, having dreamed just a while ago to be a butterfly? Or am I butterfly currently dreaming to be man? Such a doubt is equivalent to doubting if I am alive having dreamed dead or I am dead now dreaming alive. Either doubt makes sense, for "sense" is inherent in each state of affairs, dreaming or awakening, living or in death.

2) Death is thus as real as life, as dream is as real and awakening aware; they are only different one from the other. The deathly real is as natural alive as the lively real, only differently each from the other. Both are inter-distinct to inter-change, natural and alive. Such is the stunning message alluded to in this simple ordinary story of Chuang Tzu dreaming as butterfly, only to be awakened to scratch his head.

3) We need not go into fine detailed discussions on butterfly-as-entity vs. butterfly-as-medium, or on whether the butterfly itself is alive or not, and so on. We do not quite understand any of these issues anyway. It is enough that the story of "butterfly, dream, and man" are concerned with life and death mutually distinct and inter-changing one into another. Moreover, both senses, life and death, are natural alive. That is the point of Chuang Tzu dreaming to be a butterfly. Now, it may seem odd to say that death is alive, but this point implicit here is brought out in the last fabulous skull-story below.

Death-Story Three, Lady Beautiful Happily Kidnapped (2/79-81):

To graphically capture an alternative scenario to our usual gloomy view of death, Chuang Tzu further gives us this colorful story. The story runs bare two lines in the terse original Chinese words. In the briefest parsimony of typical classical history-narrative, this story packs the thickest of feelings in the kidnapping of Lady Beautiful elegant and noble, for no kidnapping lacks pathos.

1) The story goes placidly this way, as if nothing was the matter. "Lady of Beauty is daughter of Ai border-man. When Chin State first got her, her tears drenched her neckline- - until reaching the king's place, sharing square bed with the king, eating grass-fed meat, and then she repents of having been in tears. How would I know the dead would not repent of their having pined after life?”

Reconstructed in today's story line, the story could go somewhat as follows. Lady Beautiful, the cherished treasure of the border-guard at Ai, is suddenly kidnapped by a barbarian

\footnotetext{
${ }^{26}$ This is my refurbished version of William Wordsworth's "The Child is father to the Man" in his "My Heart Leaps Up When I Behold" (1802), line 7, in The Complete Poetical Works of William Wordsworth: Student's Cambridge Edition, Boston: Houghton Mifflin Co., 1904, p. 277. This original version already delivered an impact so powerful as to set Sigmund Freud onto his psychoanalysis and his disciple Erik H. Erikson onto his psychology of biography.
}

Chief of the Chin. Lady Beautiful is transported in tears drenching her entire robe, traveling to the Chief's residence. No sorrows can be comparable to such shocking miserable misfortune!

And then, her Ladyship at the royal residence is nightly treated to the world's most expensive square-bed available, such as the highest grade of Sears' Posturapedics, as she is also daily treated to the choicest grass-fed steak such as specially custom-prepared by Ruth-Chris, for the kind and gentle Chief has money aplenty for all their needs. By and by, her Ladyship comes to wonder why she had to shed tears at being "kidnapped" this way in the first place. Now, how can we be sure that the dead folks are not having a second thought about their initial wailing after life?

2) So, here are new definitions of words. "Kidnap" shows a view from our usual life-perspective. "Having a second thought" tells of revolution of point of view from "life" to "death". From the point of view of death, death may well be quite enjoyable, and this "may be" can never be disproved conclusively from the point of view of life, whose logic is completely distinct from death-logic, as dream-perspective utterly differs from awakening-perspective, as shown in the prior butterfly-dream story.

With a wry smile, Chuang Tzu says that we ourselves are her Ladyship ready anytime to be happily kidnapped by the gracious barbarian Chief Death, to be treated very royally well. However incredible it may sound, at least this is a distinct possibility no argument whatever can dispel, and there is nothing in life to prevent us from jumping at this glorious possibility, right?

3) All this is so incredible that Karl Marx had to famously proclaim such otherworldly stuff as "opium”-poor he, he did not know Chuang Tzu, much less these happy death-stories so this-worldly—as if he had a rationale for saying so, ${ }^{27}$ and all cynics in their sour-grape mindset rush to join Marx. They all dogmatically assert that all such rosy claims on death are a desperate pie in the sky. They never know that our grapes, delicious never sour, are not unreachable.

They insist, "Lady Beautiful being happily kidnapped by kind Chief Death" is a rosy claim of fool's paradise of death as Joy, which is of course just a dream, a delusory drawing of empty happiness. Still, these critics are not sure if this "drawing” is really a delusion or not. Isn't Pascal's wager for a kind all-powerful god faraway just a barren rerun of ancient Chuang Tzu's colorful "wager for" a kind barbarian Chief Death closeby? In any case, there is nothing among us living to prevent us from jumping on to such a delicious death-possibility so natural so alive.

If someone still ridicules us for embracing a "fool's paradise," we can easily retort that his-it is usually a boorish "his"-possible "cynic's hell" is just as baseless, and gives us worse aftertastes to boot, worse off than moping around at unreachable sour grapes, for he is not even sure that our delicious grapes cannot be reached. In short, the kind Chief Death remains our distinct option so daring, so natural, and so pleasant alive.

4) And so, we have an easy counteroffer to make with smile to Karl Marx. Delusion for delusion, which one would we embrace? Fool's paradise and cynic's hell, both are beyond the

\footnotetext{
${ }^{27}$ That religion is opium makes sense on three assumptions. One, life is nothing but pain and evil. Two, life has nothing beyond it or after it. Three, Marx assumes that both assumptions are self-evident. But they are not, nor can they be proven, either, since such assumptions go beyond life, and none of us has logic beyond life to prove them.
} 
grave, impossible to prove with our life-logic on this side of the grave, as dream-logic of reality is no awakened-logic of reality (the dream-story says so).

Besides, importantly, are we sure we are awakened? Are we sure we are not insisting "we are of course awakened" while we may be insisting to be awake in our dream? If we are not sure of what we are, how could we argue that death-joy is no joy? All this is just a rehearsal of Chuang Tzu's Story Two, the dream-story. In all, then, we would rather embrace our fool's paradise of her Ladyship that is as "baseless" as Marx's cynic's hell of non-existing sour grapes.

Death-Story Four, Bosom Friends Happily Seeing Off Their Friend to Death (6/45-51, etc.):

After disposing of cynical doubt on the joy of death of her Ladyship, we are now in for the joy as communal (in this story), and as alive (in the next story). This story here is about the intimate heart-known friends joyously seeing their bosom friend off to death-journey. As I translate it, it goes as follows.

Mr. Oblation, Mr. Carriage, Mr. Plow, and Mr. Come met together and said, "Who can take nothing as neck, life as back, and death as rump? Who knows death, life, surviving, and losing life, all as one body? We would befriend him.” They inter-looked; and laughed. Nothing was against their hearts; they end up becoming mutual friends.

Suddenly, Mr. Carriage got sick. Mr. Oblation went visited him, who said, "Great! The Thing-Maker is making me so crooked as this! ‥ [He] may change my left arm into a rooster, and then I'll watch for night-timing. [He] may change my right arm into a bow-pellet, and then I'll watch for an owl-roast. [He] may change my rump into wheels, my pep into a horse, and then I'll ride it; why need I change ride? ...”

1) This amazing death-story goes on like this for much longer, to cover half of the whole Chapter Six of Chuang Tzu's, but this much is enough to show three novel points. One, bosom friends in camaraderie are here in life toward death. We do not need to die alone. Two, those friends can see us off onto death-journey in joy. Death is a joy, a part of the logic of laughter. Three, the death-journey so joyous has a destination constantly expanding, beyond a definite place, as part of being natural alive.

A group of bosom friends are joyously seeing off their closest friend in death-throe into joyous journey into death. The joy of death-journey is vastly communal, involving so many nonsentient existents imaginable and unimaginable. It is important to see what the tie is that intimately binds them into bosom friends. This tie is that myriad things birthing in dying in all time and all spaces are embodied in these friends deep and vast, to naturally gather in camaraderie un-dissolvable. Their togetherness mirrors the community of myriad bosom friends in Heaven and Earth. They are cosmic joys writ small, vastly natural alive through all varied deaths into births.

2) While these many friends happily see their dearest friend off to a happy death-journey, incredibly, none of them knows the destination to which the happy journey goes. Perhaps the destination of death is an ongoing process of change alive from one state of being to another. The wearisome life-transmigration of Buddhism seems to twist here into positive uncertainty, to which our death-journey looks forward.

3) Isn't it incredible once more, though? How could death be alive? How could death be ongoing? We have seen in the butterfly-dream story how death is ongoing back and forth, and in the next final death-story of dream-talk with a skull on how cosmically alive death is, so vibrant.

Death-Story Five, Happy Dry Skull (18/22-29):

That death as a communal joy is indeed Joy cosmic and exquisite is actually reported in this story of Chuang Tzu's, dream-talking with the most miserable death, concretized in a roadside $^{28}$ skull. Here is my translation, as literal as I could make it.

“Chuang Tzu went to Ch’u, and saw an empty skull, bared, still in shape. Tapping it with a horsewhip, Chuang Tzu asked, 'Sir, did you come to this by losing reason, with greed for life? Or did you meet loss of a state, assassinated by axe or spear, to turn like this? Or had you done deeds not-good, so worried that you'd shame parents and wife and children, as to turn like this? Or were you troubled by chill and famine into this? Or was it your seasonal years that turned into this?' Words done, he pulled the skull as pillow and slept."

Now, Chuang Tzu could not help but ask this way, seeing that Confucius, Socrates, Buddha, Jesus, and even Chuang Tzu, were all decently buried. Even after beheading a criminal, the corpse is usually buried whole with the head back on. Thus to have only the skull, and that casually tossed on roadside so long as to be dry and brittle as can be, is the rock-bottom misery of any life that we can imagine. The skull was parched and still in shape enough for Chuang Tzu to pillow on it to sleep that night. And then things happened, so incredible.

"At midnight the skull appeared in a dream, saying, 'Your words are like the quibbler's, all about troubles of the living. Once dead, I have none of such. Do you, sir, wish to hear about death's joy?' Chuang Tzu said, 'Yes!' The skull said, 'Death has no ruler above, no subject below, or matters unfinishable throughout four seasons. Only unhurriedly with Heaven-Earth I make spring-autumn. Not even the awesome royalty can go beyond it.'

Chuang Tzu, incredulous, said, 'If I have Destiny Manager to revive your form, remake your bone, flesh, and skin, and return you to parents, wife-children, neighbors-acquaintances, would you like it?' The skull with deep forehead-wrinkles said, 'How could I discard this royal joy to return to labors among people?'”

1) Listening to this delightful death-story, we suddenly see that all four stories rehearsed before are culminated in this story. Chuang Tzu simply goes along with the process of his wife's death as we all goes along with shifts of four seasons (story one); the skull here blends in with spring-autumn seasons. Dreaming as butterfly, and then awakening from the dream (story two), we realize that all things and their life and death are inter-distinct in inter-change; the death-skull here dream-talks with Chuang Tzu living, to convey sheer joy of seasonably changing with myriad things.

Her Ladyship is continually being treated so royally by Chief Death (story three); are we sure Chuang Tzu is not being treated kindly by the death-skull here after all? The wearisome life-transmigration of Buddhism seems to twist here into positive uncertainty, to which our death-journey looks forward after pain has done its worst to the skull. The bosom friends cocongratulate with their dear dying friend, happily seeing him off to death-journey (story four); with vast Heaven and Earth in delightful camaraderie, the skull here joyfully performs rounds of seasons.

\footnotetext{
28“Roadside" is my addition; it is my only natural inference from how Chuang Tzu pointed at it with a horsewhip and pillowed it and slept.
} 
2) Now the culminating conclusion of this final death-story, death as Joy Ultimate, natural alive, the Joy of all joys out of all sorrows, is so extraordinary, so unheard-of, and therefore so incredible, as to provoke, quite naturally, some comments. Just three of our surprises to be mentioned here is enough to illustrate our incredulity.

To begin, amazingly, this death as joy requires no supernatural miracle to pull off. It is quite natural alive. Moreover, how could death-joy be so natural alive as to be the envy of life, the be-all and the end-all of all living natural alive? The idea is a veritable revolution of our usual "natural alive." Finally, this revolution is pulled off as "death as Joy Ultimate" by, of all things, the most insignificant skull dried and tossed on roadside, achieved and announced by the most miserable of all deaths, a casual skull so parched that none would take a second look at. These three surprising contrasts boggle our mind.

Such is the astounding apex of Chuang Tzu's series of death stories we have read that culminates in this skull-story, so incoherent yet so natural alive. But then, we take this skull-story as incoherent, because its/his extraordinary cosmic claim to cosmic joy clashes with its puny insignificance, as no one would care for such nuisance-skull uselessly tossed out somewhere not even mentioned by Chuang Tzu.

3) Our sense of such inordinate contrasts originates in our obsession with this side of the grave. We judge the skull from the viewpoint of this life. The whole point of the skull-story, the ultimate-death story, however, is precisely to offer a revolution of standpoint, from this life as solely all-important, to death that is life-beyond (which we just take as of no account from the viewpoint of this side of the grave). Once we stand on the side of death where the skull enjoys itself so very much, we would understand that its "extraordinary claim” of death as Joy is quite natural alive.

As gently told by the skull to do, we stand in death to look back at life, and the whole world totally shifts its outlook. We will then see that death is never the end of the world; death begins it. It is now the dead people who truly speak-in the classics, in history, in nature, and in death-while we the briefly living are mere chatterboxes shooting the breeze, puffing whiffs to while away life. It is death that is truly "natural alive,” and we who live for a while-about just a centuryprepare ourselves for its happy entrance.

4) All sorrows are exhausted in achieving death, ushering the living beyond life into death. Now what is left is no-sorrow, cleansed of all clutters, nicknamed "joy of no joy." It is "no joy" while blended in-performing—vast season-rounds. Such doing of no doing is so vast and clean that it can only feel as a sort of clean "joy." This "joy" is ultimate; no higher, no vaster, no calmer joy can be felt.

This is Joy beyond all joy, Joy cleansed of all sorrows. Since no living ones, whatever they are, would even dare, much less can, claim such cosmic blend-in, such pervasive no-performance, Joy Ultimate properly belongs to dead people alone. In short, nothing but joy is left in death. The dead is the happiest, to whom we the living all look forward. Our temporary life is a mere preparation for this glorious Joy eternal.

5) Kant's space-time logic is the logic of the living. Dead folks are beyond time-space, without time and without space, ${ }^{29}$

\footnotetext{
${ }^{29}$ Watch out! "Without space and without time in death" is not "space-less and timeless in disembodied thinking," for bodily death is thinkable in body thinking alone. Death-joy beyond time and space can happen only in the realm of body thinking quite situation-sensitive. Disembodied thinking is never sensitive to the concrete situation.
}

so they are "here now" any time, any place. "Here" and "now" are situation-sensitive ${ }^{30}$; dead people are situation-sensitive always. My dead folks show their joys diversely in my diverse situations, each different in each differing situation. The dead are relevant each moment, any time any place, alive so natural to us always.

That is eternity sensitive alive only the dead achieve. Plants are closest to such eternity. Plants are true unmoved movers natural alive, ever moving us and moving with us without themselves moving, talking to us without words, each time different from another. Dead folks are our plants so eternal, natural, and ever alive. Eternity situation-sensitive, actual-embodied this way, is eternity full and alive, in contrast to eternity of disembodied thinking that is eternity-hollow scarecrow.

We must repeat on this eternal joy so incredible. All these dead beings have nothing but joy, for all sicknesses, despairs, pain, injustices, miseries, and disasters have perpetrated their worst to usher these people into this scintillating world of Joy beyond all joys beyond the grave beyond all sorrows, all so natural alive. We living here now have nothing but joy to look forward to this Joy. This is the stunning Gospel of Ultimate Joy, natural alive, ${ }^{31}$ that Chuang Tzu matter-of-factly divulged to us through his dream-talk with death, with that casual skull somewhere.

6) This extraordinary fact is packed in the fabulous Joy of “with Heaven-Earth unhurriedly performing-making-doing 為 the spring-autumn 春秋 rounds of cosmic seasons” (18/27). No living being whatever would dare, much less can, claim such a magnificent performing of vast season-rounds in cosmic Joy.

And remember. The "cosmos" is quite a community all hustling and bustling, all natural and all alive. Just think. All the dead entities eternal and beyond time since time immemorial must be much more numerous and more bustling than the whole world of living entities here now put together. We say that "they are gone on", and "on” is their major thrust natural alive.

Moreover, to repeat, as I walk my daily walk, every "same" thing comes out different. Sidewalk, air, breeze, wood fence, blue sky, the heat, the sunlight, anything I see and feel, even what I feel inside, even memories that haunt, all go through me differently each time I walk by them identical outside. So does every trivial detail that is my "plant" talking in silence, shading me restful. They are all same different, different in same, same as different. That is eternity, for ever natural alive. They stay set as dead and as stable death, and as such they are alive quite joyous.

7) And, of course, in this death-joy, all this-worldly ambitions are flatly leveled off. Not a single royalty can take a single penny of his glory into the beyond-grave. Here, all dead paupers are as great as all dead princes. "Who is the greatest in the kingdom of death?” is as utterly silly a question as asking which tree is the greatest in the all-lush forest. Everyone dead is in great joy.

\footnotetext{
${ }^{30}$ Logicians call them “demonstratives”, as special words; see Palle Yourgrau, ed., Demonstratives, Oxford University Press, 1990. But actually all common nouns are such demonstratives, for "[a specific] white horse is no horse [in general]”, China’s name-logician Kung-sun Lung alerts us.

${ }^{31}$ This must also be Jesus' Gospel, though in much less natural terms, so perhaps less credible, yet as alive. Some passages in the New Testament may be made more intelligible in this context of "natural alive, e.g., marital status after death” (Luke, 20: pp. 34-35), and perhaps Beggar Lazarus beside Abraham (Luke, 16: pp. 19-31).
} 
Death levels everyone into the identical yet various ultimate Joy of all joys, as all world religions promise. Amazingly, Chuang Tzu does not promise; he matter-of-factly divulges this deathly joy to us, with an actual report of his dream-talk with death, concretized in the most abject skull all dried up. This is body thinking in all its glories!

8) "Now be reasonable, pal. How could dead people be happy? Aren't they just nothing?” My dear friend, your "being reasonable" is reasonable among the living. Let me try this explanation. Only when we have something, do we feel loss and pain, right? So, the less we have, the less pain we have, until we have nothing, to have no pain. So, the dead person having nothing, not even himself, is in peace without groan, happy in silence. Such is Buddhist Nirvana of absolute calm.

Chuang Tzu's friendly skull shows as much, but he is no Buddhist, for the dead skull is not calm but does do rounds of spring-autumn seasons with vast Heaven and Earth, in sheer cosmic joy. The spring begins summer, and the autumn begins winter to begin spring. And so, "spring autumn" is a phrase with the beginning-thrust of seasons turning, turning, without ceasing. The skull is a happy part of these cosmos-dynamic turnings forever beginning undying.

Let me put it another way. The baby has nothing, so she giggles for nothing, and absolutely no one can resist her. Chuang Tzu's skull is the darling baby of father Heaven and mother Earth, giggling always for nothing, being so natural alive a baby. Music is joy resounding in nothing for nothing. Chuang Tzu's skull pipes the organ-music of seasons in nothing. The skull is cosmic music of the cosmic baby, happy as can be.

Besides, there is nothing-as-full and there is nothing-as-hollow. Baby-nothing alive is full, while a dummy owl the scarecrow to foxes is just a hollow. Can Buddhism distinguish a baby from a dummy owl? Dead people are a happy nothingbaby alive, not a dummy owl hollow.

This is because death assumes having been born as life lives to death (the dream-story says so), while hollow-owl is just hollow of such live dialectic of "distinct" and "inter-change." Silence is charged music while calm is not. Nature alive-asbaby is silence-music; it is Chuang Tzu's "heavenly piping” beyond and behind the sound of music of the myriad.

Children are spontaneous "piping music”. A boy mumbles that he does not know if he knows anything he does not know, and then confesses that he does not know someone he has not met. Wow! No adult logician can refute any of his claims! This is because our adult logic is nothing but an unpacking of all his claims. The boy-nothing is so full, so invincible, for he is so natural alive. Dead people are a nothing-alive boy just growing up cosmically and happily, as if nothing matters.

9) I hope we are now convinced that the joy of death natural alive arrives by our actuality-thinking in story-thinking, enlivened by body thinking. Disembodied thinking has no actuality so unpredictable, no story so wayward, and no body so fragile, yet this fragile, wayward and unpredictable body thinking supports disembodied thinking so predictable, stable, and eternal.

This puff of disembodied thinking is a teenager looking down on his own "parents so clumsy, so shamefully dated, and so impossibly incapable.” Growing up, he would be stunned to see how quickly they have grown up so wise ahead of him. Disembodied thinking could also turn itself around by learning from body thinking in time, in contingency, and in bodily death in ultimate joy.

Body Thinking Pivotal in Life
Physiological body in disembodied thinking ceases at death, while physical body, as phusis, ${ }^{32}$ keeps naturing, making seasonal rounds with heaven and earth, precisely in bodily death, as China describes above. As soon as we body-think, we are led into even death-as-joy as Chinese body thinking shows us, besides being enabled to thrive in shifting "time" and uncertain "contingency", ubiquitous and incorruptible, literally world without end.

This is simply because nothing is more important than life that includes bodily death; and if life is as protean and unpredictable as history describes it, then body thinking is as bottomlessly alive and fascinatingly mysterious as life is. Being hydra-headed and quite bottomless, so fascinating so pivotal, body thinking ${ }^{33}$ does deserve spreading worldwide, beginning at China to spread to the West, doesn't it?

\section{REFERENCES}

Arendt, H. (1970). On violence. New York: Harcourt, Brace, and World.

Baskin, W. (Ed.) (1965, 1974). Jean-Paul Sartre: Essays in existentialism. Secaucus, NJ: Citadel Press.

Beck, L. W., Tr. (1949). Kant's critique of practical reason and other writings in moral philosophy. Chicago: University of Chicago Press.

Bretall, R. W. (Ed.) (1963). The empirical theology of Henry Nelson Wieman. Carbondale: Southern Illinois University Press.

Handyside, J. Tr. (1929). Kant's inaugural dissertation and early writings on space. Chicago: Open Court.

Confucius, The Analects.

Honderich, T. (1976). Political violence. Ithaca, NY: Cornell University Press.

Kemp, S. N. (1965). Immanuel Kant's critique of pure reason. New York: St. Martin's.

Kierkegaard, S. (1941). The sickness unto death. Princeton: Princeton University Press.

Kohlenberger, J. R. III, Goodrick, E. W., \& Swanson, J. A., (Eds.) (1997). The Greek-English concordance to the new testament. Grand Rapids, MI: Zondervan.

Kushner, H. S. (1981). When bad things happen to good people. New York: Schocken Books.

Laozi, Daodejing.

Lehrer, K., \& Beanblossom, R. E. (Eds.) (1975). Thomas Reid's inquiry and essays. Indianapolis: Bobbs-Merrill.

Liddell, H. G., \& Scott, R. (1996). Greek-English lexicon. Oxford: Clarendon Press.

Lin, Y. (1942). The wisdom of China and India. New York: Random House.

McArthur, T. (Ed.) (1992). The Oxford companion to the English language. Oxford: Oxford University Press.

Merriam-Webster's Collegiate Dictionary (2008).

Oxford English Dictionary (2001). (2nd ed.). Oxford: Clarendon Press.

說文解字詁林 (1983). 臺北市鼎文書局. Collected Commentaries on Encyclopic Dictionary of Etymology. Taipei: Ting-wen Publishers

The Mencius.

Merleau-Ponty, M. (1962). Phenomenology of perception. London: Routledge \& Kegan Paul.

Merleau-Ponty, M. (1964). The primacy of perception. Evanston, IL: Northwestern University Press.

Merleau-Ponty, M. (1968). The visible and the invisible. Evanston, IL: Northwestern University Press.

\footnotetext{
${ }^{32}$ See "$\varphi v \sigma ı$ " in H. G. Liddell and R. Scott, Greek-English Lexicon, Clarendon Press, Oxford, 1996, p. 1964, and "physic" in Oxford English Dictionary, Second Edition, 2001, XI: 743.

${ }^{33}$ I have considered "body thinking" in many other contexts in diverse directions, in my Chinese Wisdom Alive (2010), in Story-Thinking (2011), in The Beyond (2013, forthcoming), and in Interculture (forthcoming), all from Nova Science Publishers, in New York. I omit articles, and cite here body thinking that appears just in Story-Thinking, pp. 291-362 and 414-438.
} 
Merleau-Ponty, M. (1973). The prose of the world. Evanston, IL: Northwestern University Press.

Nagel, T. (1989). The view from nowhere. Oxford: Oxford University Press.

Rée, J., \& Urmson, J. O., (Eds.) (2005). The concise encyclopedia of western philosophy. London: Routledge.

Reese, W. L. (1999). Dictionary of philosophy and religion. Amherst, NY: Prometheus.

Santayana, G. (1923, 1955). Scepticism and animal faith. New York: Dover.

Santayana, G. (1926, 1948). Dialogues in limbo. New York: Charles Scribner's.

Schilpp, P. A., \& Hahn, L. E. (Eds.) (1984). The philosophy of gabriel marcel. La Salle, IL: Open Court,

Spicker, S. F. (Ed.) (1970). The philosophy of the body: Rejections of cartesian dualism. Chicago: Quadrangle Books.

Urmson, J. O. (1968). The emotive theory of ethics. Oxford: Oxford University Press.

Waley, A. $(1939,1982)$. Three ways of thought in ancient China. Stanford: Stanford University Press.

Wordsworth, W. (1904). The complete poetical works of William Wordsworth: Student's Cambridge Edition. Boston: Houghton Mifflin Co.
Wu, K. (1990). The butterfly as companion. Albany: State University of New York Press.

Wu, K. (1997). On Chinese body thinking: a cultural hermeneutic. Leiden: E. J. Brill.

Wu, K. (2001). On metaphoring: A cultural hermeneutic. Leiden: Brill.

Wu, K. (1998). On the "Logic" of togetherness: A cultural hermeneutic. Leiden: Brill.

Wu, K. (2010). Chinese wisdom alive: Vignettes of life-thinking. New York: Nova Sciences.

Wu, K. (2011). Story-thinking: Cultural meditations. New York: Nova Sciences.

Wu, K. (2012). Nonsense: Cultural meditations on the beyond. New York: Nova Sciences.

Wu, K. (Ed.) (2012). Globalization dynamics. New York: Nova Sciences.

Wu, K. (2013). THE BEYOND: A CULTURAL MEDITATIONS ON RELIGIONS. New York: Nova Sciences.

Yourgrau, P. (Ed.) (1990). Demonstratives. Oxford: Oxford University Press.

Zhang, Z. (2008). Traditional Chinese philosophy as the philosophy of the body. Beijing: Chinese Social Sciences Publishers.

The Zhuangzi. 